\title{
Neonatal neuroradiological aspects in Zika virus infection
}

\author{
Viroj Wiwanitkit ${ }^{1,2}$
}

Received: 19 April 2016/Accepted: 26 April 2016/Published online: 30 April 2016

(C) Springer-Verlag Berlin Heidelberg 2016

\section{Dear Editor,}

The recent report on Zika virus is very interesting [1]. Cavalheiro et al. "analyzed 13 cases of newborns with microcephaly born to mothers who were infected by the Zika virus in the early stage of pregnancy" and concluded that "there is a definitive pathognomonic radiographic pattern of microcephaly caused by Zika virus, gross calcifications and anarchic distribution involving the subcortical cortical transition and the basal ganglia, in association with lissencephaly and in the absence of hypertensive ventriculomegaly, are characteristic of this type of infection [1]." Of interest, this small study might not lead to a conclusion. In a larger study, it was reported that observation that "brain calcifications in the junction between cortical and subcortical white matter associated with malformations of cortical development, often with a simplified gyral pattern and predominance of pachygyria or polymicrogyria in the frontal lobes [2]." Based on the two studied, the only conclusion should be the observation on brain calcification which is a non-specific finding. Also, there is an interesting question for Cavalheiro et al. whether if there is any relationship between gestation age of the neonate and the observed pathology. Since the development of neurological system is different at different gestational age.

\section{Compliance with ethical standards}

Conflict of interest No confict of interest.

\section{References}

1. Cavalheiro S, Lopez A, Serra S, Da Cunha A, da Costa MD, Moron A, Lederman HM. Microcephaly and Zika virus: neonatal neuroradiological aspects. Childs Nerv Syst 2016 Apr 14. [Epub ahead of print]

2. de Fatima Vasco Aragao M, van der Linden V, Brainer-Lima AM, Coeli RR, Rocha MA, Sobral da Silva P, Durce Costa Gomes de Carvalho M, van der Linden A, Cesario de Holanda A, Valenca MM. Clinical features and neuroimaging (CT and MRI) findings in presumed Zika virus related congenital infection and microcephaly: retrospective case series study. BMJ. 2016 Apr 13;353:i1901.
Viroj Wiwanitkit

wviroj@yahoo.com

Surindra Rajabhat University, Surin, Thailand

2 Bangkhae, Bangkok, Thailand 